\title{
Comment
}

Neuroepidemiology 2016;47:18-19

DOI: $10.1159 / 000446993$

\section{The Future of Statins: Essential Tremor?}

\section{Julián Benito-León ${ }^{\mathrm{a}-\mathrm{c}}$}

a Department of Neurology, University Hospital '12 de Octubre', ${ }^{b}$ Centro de Investigación Biomédica en Red sobre Enfermedades Neurodegenerativas (CIBERNED), and ' Department of Medicine, Complutense University, Madrid, Spain

Essential tremor (ET) is a progressive condition that is clinically heterogeneous, as it may be associated with a spectrum of clinical features with both motor and nonmotor elements [1, 2]. The risk and etiological factors for ET have not been clearly established; however, recent research suggests that several environmental factors [3], including neurotoxins (e.g. lead and harmane) [4], cigarette smoking $[5,6]$, high levels of ethanol consumption [7], shorter sleep duration [8], or head trauma [9] may play an etiological role in ET, whereas other studies demonstrate genetic causes [10]. These findings may not be mutually exclusive; indeed, environmental factors might work in concert with underlying susceptibility genotypes [11]. Although the biological mechanisms that underlie ET are not completely understood, there is an open and active dialogue in the medical community as to whether ET is a neurodegenerative disease, with considerable evidence in favor of this $[12,13]$. Published studies have demonstrated that oxidative stress plays a central role in a common pathophysiology of neurodegenerative diseases such as Alzheimer's disease and Parkinson's disease (PD) [14]. In addition, a number of authors have reviewed the role of statins in these 2 neurodegenerative diseases $[15,16]$. Among the recognized pleiotropic effects of statins are their antiinflammatory and antiendothelial dysfunction activities, as well as their antioxidant, profibrinolytic, or antiproliferative properties [15].

Despite the links between ET and other neurodegenerative diseases [17-20], and an increasing appreciation that ET itself may be a neurodegenerative disease [13], an association between statin use and the odds of ET had not been formally assessed.

In this issue of Neuroepidemiology, Shalaby and Louis [21] probe whether statin use differed in ET cases vs. controls and PD cases vs. controls. The results confirm a marginally significant inverse association between $\mathrm{PD}$ and statin use. In addition, although in primary analyses there was no evidence that statin use was protective in ET, there was an inverse association in analyses that assessed longer-term use of statins.

The study had several strengths, including the large sample size, the fact that cases had all received a diagnosis of ET or PD that was carefully assigned by a movement disorder neurologist, the inclusion of a disease group (PD) with a well-known inverse association with statin use, and a well thought-out approach to the statistical analyses. The study was not without limitations. As noted by the authors, this was a case-control study rather than a cohort study, and hence, this precludes direct inferences about causality in the relationship between statin use and neurological diseases. Second, statin use was assessed by self-report, rather than pharmacy records. Finally, the study was powered to detect a doubling in the proportion of statin users across diagnostic groups; subtler group differences might not have been detected. The authors were aware of the limitations and, to their credit, provided a thoughtful discussion of these issues, indicating why they thought these issues were of less concern in this study.

Leaving aside issues of strengths and limitations, the study suggests for the first time that there is an inverse association between longer-term use of statins and ET and this is an important discovery. A better understanding of the anatomical and pathological bases of this disorder will lead to advances in the development of more effective symptomatic treatments, and also possibly neuroprotective treatments.

\section{Study Funding}

No targeted funding reported.

\section{Disclosure Statement}

The author reports no disclosures relevant to the manuscript.

\section{References}

1 Benito-León J, Louis ED: Essential tremor: emerging views of a common disorder. Nat Clin Pract Neurol 2006;2:666-678.

2 Benito-León J, Louis ED: Update on essential tremor. Minerva Med 2011;102:417-440.

3 Jiménez-Jiménez FJ, de Toledo-Heras M, Alonso-Navarro H, AyusoPeralta L, Arévalo-Serrano J, Ballesteros-Barranco A, Puertas I, JabbourWadih T, Barcenilla B: Environmental risk factors for essential tremor. Eur Neurol 2007;58:106-113.

4 Louis ED, Benito-León J, Moreno-García S, Vega S, Romero JP, Bermejo-Pareja F, Gerbin M, Viner AS, Factor-Litvak P, Jiang W, Zheng W: Blood harmane (1-methyl-9h-pyrido[3,4-b]indole) concentration in essential tremor cases in Spain. Neurotoxicology 2013;34:264-268.

5 Benito-León J, Louis ED, Bermejo-Pareja F; Neurological Disorders in Central Spain (NEDICES) Study Group: Population-based case-control study of cigarette smoking and essential tremor. Mov Disord 2008;23: 246-252.

6 Louis ED, Benito-León J, Bermejo-Pareja F; Neurological Disorders in Central Spain (NEDICES) Study Group: Population-based prospective study of cigarette smoking and risk of incident essential tremor. Neurology 2008;70:1682-1687.

\section{KARGER}

E-Mail karger@karger.com

www.karger.com/ned
C 2016 S. Karger AG, Base

0251-5350/16/0471-0018\$39.50/0
Dr. Julián Benito-León

Department of Neurology

Avda. de la Constitución 73, portal 3, $7^{\circ}$ Izquierda

Coslada, ES-28821 Madrid (Spain)

E-Mail jbenitol67@gmail.com 
7 Louis ED, Benito-León J, Bermejo-Pareja F: Population-based study of baseline ethanol consumption and risk of incident essential tremor. J Neurol Neurosurg Psychiatry 2009;80:494-497.

8 Benito-León J, Louis ED, Bermejo-Pareja F: Short sleep duration heralds essential tremor: a prospective, population-based study. Mov Disord 2013;28:1700-1707.

9 Benito-León J, Louis ED, Labiano-Fontcuberta A, Bermejo-Pareja F: Serious head trauma preceding essential tremor: a population-based study (NEDICES). J Neurol Sci 2015;353:116-121.

10 Jiménez-Jiménez FJ, Alonso-Navarro H, García-Martín E, Lorenzo-Betancor O, Pastor P, Agúndez JA: Update on genetics of essential tremor. Acta Neurol Scand 2013;128:359-371.

11 Louis ED, Applegate L, Graziano JH, Parides M, Slavkovich V, Bhat HK: Interaction between blood lead concentration and delta-amino-levulinic acid dehydratase gene polymorphisms increases the odds of essential tremor. Mov Disord 2005;20:1170-1177.

12 Benito-León J: Essential tremor: one of the most common neurodegenerative diseases? Neuroepidemiology 2011;36:77-78.

13 Benito-León J: Essential tremor: a neurodegenerative disease? Tremor Other Hyperkinet Mov (N Y) 2014;4:252.

14 Kim GH, Kim JE, Rhie SJ, Yoon S: The role of oxidative stress in neurodegenerative diseases. Exp Neurobiol 2015;24:325-340.

15 Sánchez-Ferro A, Benito-León J, Mitchell AJ, Bermejo-Pareja F: A review of the potential therapeutic role of statins in the treatment of Alzheimer's disease: current research and opinion. Neuropsychiatr Dis Treat 2013;9: 55-63.

16 Paul R, Choudhury A, Borah A: Cholesterol - a putative endogenous contributor towards Parkinson's disease. Neurochem Int 2015;90:125133.

17 Benito-León J, Louis ED, Bermejo-Pareja F; Neurological Disorders in Central Spain Study Group: Risk of incident Parkinson's disease and parkinsonism in essential tremor: a population based study. J Neurol Neurosurg Psychiatry 2009;80:423-425.

18 Benito-León J, Louis ED, Bermejo-Pareja F; Neurological Disorders in Central Spain Study Group: Elderly-onset essential tremor is associated with dementia. Neurology 2006;66:1500-1505.

19 Bermejo-Pareja F, Louis ED, Benito-León J; Neurological Disorders in Central Spain (NEDICES) Study Group: Risk of incident dementia in essential tremor: a population-based study. Mov Disord 2007;22:15731580 .

20 Jiménez-Jiménez FJ, Alonso-Navarro H, García-Martín E, Agúndez JA: The relationship between Parkinson's disease and essential tremor: review of clinical, epidemiologic, genetic, neuroimaging and neuropathological data, and data on the presence of cardinal signs of parkinsonism in essential tremor. Tremor Other Hyperkinet Mov (N Y) 2012; 2:pii:tre-02-75-409-3.

21 Shalaby SY, Louis ED: Statin use and its association with essential tremor and Parkinson's disease. Neuroepidemiology 2016;47:11-17. 